Canadian University Music Review

Canadian University Music Review

Revue de musique des universités canadiennes

David Lidov. Elements of Semiotics. New York: St. Martin's

Press, 1999. xvi, 288 pp. ISBN 0-312-21413-8 (hardcover)

Raymond Monelle. The Sense of Music: Semiotic Essays.

Princeton and Oxford: Princeton University Press, 2000. xvi, 248 pp. ISBN 0-691-05716-8 (paperback)

\title{
William Echard
}

Volume 21, numéro 2, 2001

URI : https://id.erudit.org/iderudit/1014490ar

DOI : https://doi.org/10.7202/1014490ar

Aller au sommaire du numéro

\section{Éditeur(s)}

Canadian University Music Society / Société de musique des universités canadiennes

\section{ISSN}

0710-0353 (imprimé)

2291-2436 (numérique)

Découvrir la revue

\section{Citer ce compte rendu}

Echard, W. (2001). Compte rendu de [David Lidov. Elements of Semiotics. New York: St. Martin's Press, 1999. xvi, 288 pp. ISBN 0-312-21413-8 (hardcover) / Raymond Monelle. The Sense of Music: Semiotic Essays. Princeton and Oxford: Princeton University Press, 2000. xvi, 248 pp. ISBN 0-691-05716-8 (paperback)]. Canadian University Music Review / Revue de musique des universités canadiennes, 21(2), 123-131. https://doi.org/10.7202/1014490ar

All Rights Reserved (C Canadian University Music Society / Société de musique des universités canadiennes, 2002
Ce document est protégé par la loi sur le droit d'auteur. L’utilisation des services d'Érudit (y compris la reproduction) est assujettie à sa politique d'utilisation que vous pouvez consulter en ligne.

https://apropos.erudit.org/fr/usagers/politique-dutilisation/ 
audience of scholars, warrants a more critical response. Brodbeck borrows overtly and covertly from the discourses of "New Musicology," with little explanation and frequently no documentation. Readers unfamiliar with the jargon of these discourses remain in the dark. Although his entire discussion is firmly rooted in a prodigious accumulation of documentary evidence, his marshalling of that evidence is not always selective or critical. Readers must wade through reams of extracts from letters and diary entries, for instance, to discover that the genesis of the Symphony prior to the 1870 s still remains shrouded in mystery. Brodbeck also falls back on quotation of documents to tell the story with little critical commentary, while his reading of the Symphony, perhaps the most significant portion of the book, is largely dependant on Kalbeck's sometimes questionable assumptions, which Brodbeck leaves unchallenged. The principal problem of this study, however, is the extent to which this all-important hermeneutic reading is interrupted by digressions that flesh out the musical contexts necessary for unpacking the meaning for various extra-compositional references. It would have been far more effective to deal with this aspect of the symphony in a preliminary chapter that enumerated not only such models and allusive sources, but also defined critically the extent of their significance. With the musical background thus sketched, the reader (and even the writer) are free to follow the vicissitudes of expression which this difficult work undergoes. Unlike Musgrave who keeps his research from clouding the presentation of his material, Brodbeck in the end sacrifices the requirements of a handbook for the sake of methodological rigor. Nevertheless, his contribution daringly probes expressive depths that hitherto still await as thorough an exploration in the music of Brahms.

Dillon R. Parmer

David Lidov. Elements of Semiotics. New York: St. Martin's Press, 1999. xvi, 288 pp. ISBN 0-312-21413-8 (hardcover).

Raymond Monelle. The Sense of Music: Semiotic Essays. Princeton and Oxford: Princeton University Press, 2000. xvi, 248 pp. ISBN 0-691-05716-8 (paperback).

Musical semiotics is at a crossroads. The field established itself in the 1970s, expanded in the 1980s, and was consolidated in the 1990s. Now, leading figures are returning to basic questions about the nature of analysis, hermeneutics, and semiosis, wishing to set a viable course for the next decade. Two such authors are David Lidov and Raymond Monelle. Monelle's book is narrowly focused on music, whereas Lidov's is a work of general semiotic theory with a special interest in aesthetics (and written by a music theorist/composer). It is profitable to read and review these works side-by-side. Lidov and Monelle have been colleagues for many years, and concern themselves with similar issues. However, while Lidov has devoted himself to refurbishing structuralist semiotics, Monelle has turned towards postmodernism. As a result, the books implicitly speak to one another, sketching divergent options on the question of 
what relationship semiotics in the new century should bear to its structuralist roots.

The preface to Monelle's book, by Robert Hatten, presents the work as a new stage for musical semiotics, one "in which semiotic theory confronts postmodernism and emerges as viable, even after relinquishing the hitherto unacknowledged hegemony of its structuralist core" (p. xi). While Hatten welcomes this new direction, he does not display an unreserved commitment to postmodernism in its more radical forms. He feels that the approach suggested in Monelle's book is "one that has absorbed the intellectual energies of postmodernism without falling into the abyss of its relativisms and indeterminacies" (p. xiii). Certainly, musical semiotics must confront the postmodern influence. I should also point out that, in the present review, I use the phrase "musical semiotics" to refer to the body of work focused on classical music. There is a substantial body of work available in the semiotics of popular music as well, but it is not cited by Monelle or by Lidov, and has had no visible effect on their work. It may be expected that workers in the semiotics of classical music, rooted in a canonical tradition and thinking within the lineages of structuralism and traditional aesthetics, would approach postmodern theory cautiously if at all. In this sense, Monelle's foray into the abyss is to be welcomed. Monelle describes his understanding of postmodernism as follows:

Postmodernism is, specifically, a rejection of unification, of manifestos, of centralizing and totalizing forces. It is both a return to pluralism after the modernist experiment and - its true novelty - an embracing of pluralism as a fundamental tenet (p. 4).

As one may expect, this becomes the starting point for a critique of systematic thought, but also a general defense of theory, which Monelle defines in a very specific sense. Theory for Monelle is not a formal science, but rather an interpretive framework applied to intentional objects. Monelle wishes to allow theory a maximum degree of autonomy, to the point where he explicitly rejects some of the culturalist and political influences often associated with the postmodern turn. Monelle asserts that theory is ahistorical. In addition, "a theory of the sense of music is not autonomous, but it is immanent, self-related, and logically prior to music sociology" (p. 6). Monelle's thinking seems divided in this respect. On the one hand, he frequently argues for the necessity of contextual, social, and historical factors as elements in musical semiosis, as when he suggests that "analysis engages with signifier and signified together, and thus reveals the musical text, which is a great deal more than merely the score" (pp. 10-11). However, he also argues for a seemingly decontextualized form of neutral analysis.

Neutral analysis will be nonnormative, nonevaluative, and not dependent on marginal accounts drawn from psychology, sociology, political ideology, or elsewhere. It will not, as some Marxists might assume, be for this reason politically disingenuous; on the contrary, the introduction of political conclusions and commitments into neutral hermeneutics is improper. Hence, this 
book (or at least, most of it) is not hostile to anyone or anything; the transcendent studies must take their proper place (p. 11).

It seems odd that Monelle should take such a position in a chapter beginning with an excerpt from Foucault, known among other things for his emphasis on the political dimensions of discourse. Although I find this pointed resistance of politics problematic, and will return to the topic, a generous reading might suggest that Monelle overstates the autonomy of the textual universe in order to allow for a form of analysis which considers intertextuality and social context, insofar as it considers the interactions between musical codes and other sorts of code, but which does not allow any kind of politicized pragmatics. I will return to the question of Monelle's ultimate place with respect to postmodern theory, and to the purported neutrality of his analysis.

Much of what Lidov says is implicitly opposed to Monelle's position, especially where the place of systems is concerned. While Lidov recognizes the limits of systematic thought, he suggests that "the alternative of blind faith in a consensual discourse risks too much that our terms will be hostage to fashion" (p. xiii). In particular Lidov argues that structuralism, despite its clear flaws and unfashionable status, should not be abandoned altogether.

Structuralism should not be sealed and posted before its letter is finished. In my view, structuralism got stuck in the hypnotic spell of some brilliant but excessively simple reductions, particularly a narrow construction of articulation and combinatory relations, a false lure that promised a closer approximation to the world of mathematics than we should hope to realize (p. 129).

One of Lidov's great achievements is to do two things with structuralism. First, he places it in a dialectic relationship with pragmatics. Second, he expands its set of formal resources with respect to the study of articulation. Besides serving to partially recuperate an important intellectual tradition, this program allows Lidov to speak about communication, a topic of great concern to him.

What must not pass without notice is that apart from [personal and social] differences, we feel that we share something, that the work of art can bring to everybody else something that it has brought to us. This is the side of the experience of art and semiosis in general that is mysterious and that cries out for some talk ... What we share or think we share or wish to share is exactly what we can attribute to the signs themselves (p. 64).

Lidov proposes to develop a semiotics rooted in structuralism, and one which takes a favourable view towards both systematic thought and trans-subjective abstractions, while remaining relatively modest and undogmatic. "My ideal for universals is Snap-On tools, portable and adaptable, not the lever with which Alchemides offered to move the world" (p. xiii).

Monelle divides his book into essays dealing with current subjects in musical semiotics, such as topic theory, temporality, textuality, and genre. In some cases he offers significant extensions to existing theoretical work, for 
example, arguing that topic theory must be pursued with a higher degree of historical contextualization, and demonstrating the nature of a more historically adequate topic theory by looking at topical aspects of the Wagnerian leitmotiv, an analysis which expands into a finely nuanced exploration of nineteenth-century topics. It is ironic, given Monelle's initial rejection of history and sociology as central elements of music theory, that a great strength of this chapter is the level of cultural and historical detail which it introduces to topic theory. Besides providing contextual nuance, Monelle also deals with important theoretical questions, such as the case in which the primary signification of a topic (the indexical or iconic links which allowed it to function in the first instance) have been forgotten. This leads to a general discussion of transfer and transformation of musical meaning.

Monelle also makes important contributions in his chapter on temporality. He distinguishes "time" from "temporality," the former being "natural" and the latter "cultural" (p. 81). His definition of the first is problematic, but his focus is mostly on the second, and on how music can signify time.

Sign systems may proceed in time; however, it is not necessarily the case that the levels of content and expression acknowledge the same temporality, or that pertinent juncture occurs correspondingly on the two levels. In other words, the levels of content and expression may be logically nonconformal. ... Language and music are temporal signs, of course, but the time within which they are structured is not necessarily connected to the time they may mean (pp. 82-83).

This leads to a critique of Jonathan Kramer's influential work on temporality, which in Monelle's opinion insufficiently distinguished between the times of the signifier and of the signified. More generally, Monelle suggests that "the failure to distinguish syntactic and semantic temporality has led to much confusion in the temporal theory of music" (p. 83). Monelle interleaves music-specific commentary with general notes about cultural temporality, citing Evans-Pritchard's distinction between ecological and structural time. Monelle develops this framework in the Western art music context, acknowledging that Kramer did likewise but trying to more effectively distinguish between signifier and signified. Following Evans-Pritchard, Monelle identifies two core temporalities for Western art music: progressive and lyric temporalities. In the course of this analysis, he also makes use of Bergson's influential theory of durée, acknowledging its problematic nature but holding to the difference between measured time and perceived time. The lack of an adequate theory of temporality is felt in all branches of music theory, semiotics included, and Monelle's work in this area is of potentially great importance.

The final area in which Monelle makes significant contributions, and the one which most clearly shows his debt to postmodernism, is his theory of textuality. Adopting a Derridean perspective, and further influenced by Rodolphe Gasché, Monelle approaches a question which has long haunted musicology: what is a musical text? 
A text is not the pattern of signifiers or signifieds, or even the patterned relation between them; on the contrary, it is the annihilation of opposition, the stage of resolution or fruition of the opposition of sign and meaning which constitutes the action of signification (p. 149).

Monelle welcomes this admittedly abstract formulation, because the relationship between signifier and signified is already notoriously blended in music. "The musical text is clearly a text in this ... sense; it is the score, not as performed, but as understood, its dialectics resolved into intelligibility" (p. 149). Monelle does, however, acknowledge the difficulties presented by such a view.

If the text is that boundary where dialectics is aufgehoben, where self and Otherness confront each other, what is to be found on that boundary? Does it exist? Can it be known or interpreted? Like so many deconstructive ideas, this merging point of the text seems to be just nothing at all (pp. 149-50).

While some may see such ontological vagueness as a fatal flaw, Monelle frames it as a strength. "The absence of musical signification, its dissolving under the studious eye, is not a limitation of music, but on the contrary its very life and beauty" (p. 150). Here Monelle distinguishes between the text and the work - the latter is a historical product which can be discussed as such-and argues that the space of the text is not the space of the work, but a textual space defined largely through intertextuality. Clearly, Monelle is tending towards the idea of a textual universe relatively autonomous from immediate social discourse, and in this respect his view is quite conservative (and problematic for those who, like myself, prefer to retain a central place for pragmatics, politics, and a non-determinist materialism). However, Monelle's presentation is more nuanced and careful than is common in this area, and his approach is true to the postmodern orientation insofar as it resists questions about how the textual universe is grounded in other sorts of reality.

It must be admitted that Monelle effectively explores some of the implications of the Derridean viewpoint in relation to musical textuality. But I find it difficult to escape the feeling that the theory could be simpler and more approachable if questions of social practice were not kept at such a distance. Bakhtin was also, in his way, a postmodern thinker (or at least a hypermodernist one), and his view of text as discourse and act could do much to remove some of the more obscurantist aspects of the Derridean perspective. However, Monelle has made his choice explicit and pursued it with a high level of sophistication, and as a result his comments will be valuable to readers of any theoretical persuasion.

Monelle's book touches upon several other subjects as well. He develops theoretical approaches to genre, structure, allegory, and deconstruction, which are similar in flavour to those described above, although not as complete. He also presents many notable case studies drawn mostly from nineteenth-century music, especially an extended discussion of Mahler. Before moving on to a 
final commentary, however, I would like to describe Lidov's work in similar detail.

Lidov's great strength is the degree to which he remains within the structuralist lineage without falling prey to its usual limitations. He offers concise synopses of existing theories, extensions to these theories, and a few carefully selected new concepts of potentially great utility. The book is less extravagant in tone than Monelle's, partly because Lidov continues to adhere to a more systematic approach, and partly because Lidov's modifications to existing theories almost always amount to simplification. In some cases, this transforms difficult and obscure models into relatively easy and useful tools. One source of this transparency is Lidov's decision to confine his analysis to conscious phenomena, and to those which are not already adequately treated by other disciplines.

We need not concern ourselves with phenomena that are well accounted for by physics nor with phenomena that seem adequately described by biology. Our business is the conscious mind. Some readers will find this attitude commonsensical, but in fact it is controversial, and other readers will find it superficial (p. 38).

Lidov presents a long but not unwieldy list of critical phenomena for semiotic research. For musicologists unfamiliar with semiotics, this discussion could be useful in giving a sense of which problems may be profitably approached with a semiotic toolkit in hand. However, Lidov's decision in favour of consciousness, while thoroughly justified on theoretical grounds, has the unfortunate effect of removing from discussion schools of semiotic thought which have proven themselves of great use to other musicologists. I am thinking here especially of the work of Barthes and Kristeva, which can certainly be questioned on ontological grounds, but which has also proven to be of great heuristic value, especially when considering social and psychological aspects of signification.

Even though Lidov's systematic orientation occasionally leads to wholesale exclusion of important areas of the literature, he still manages to engage an admirably wide range of materials. Especially noteworthy here is his emphasis on the importance of Prague Circle semiotics. Although Lidov does not deal directly with social context, his championing of the Prague Circle helps to offset this imbalance.

Saussure defined the sign as the union of signifier and signified. The Prague Circle evolved an alternative or complementary conception, that the sign was characterized by a multiplicity of effects which its members called functions (p. 57).

As I noted earlier, Monelle's relative exclusion of Bakhtin could be read as one factor leading to his ontologically extravagant concept of textuality. Although Bakhtin is mostly absent from Lidov's work as well, Prague Circle theorists such as Jakobson and Mukarovsky have presented models of enunci- 
ation with similar social concerns, and their presence within Lidov's formal structural approach is welcome.

It is the need for a semiotic theory of aesthetic experience that drives many of Lidov's theoretical decisions. Semiotics emerged originally from linguistics and the philosophy of logic, and requires some readjustment if we wish to speak of artistic concerns such as expressivity or the elaboration of expressive forms.

\begin{abstract}
What we have gained so far is an ad hoc method of parsing the social situation of the sign, perhaps a broader idea of semiotic phenomena, but not a new conception of the sign itself. But when we come to the aesthetic sign, paraphrase in this vein runs into a dead end. Either we accept the paradox of 'self-reference' or we are stuck ... Where functionalism comes closest to justifying an alternative paradigm is with the aesthetic, but in spelling out how a sign attracts value in itself, we [note] that Jakobson turned back again to the question of the structure of the signifier (p. 65).
\end{abstract}

One important step taken by Lidov in developing a semiotics of aesthetic experience is to simplify the semiotic theory of Charles Peirce, a body of work which has been of increasing importance in recent decades but which remains notoriously difficult. Lidov's version can be used profitably by those who want an accessible introduction to the essentials of Peircian thought, and should also be of considerable interest to experts in the field. Lidov uses Peirce's theory to emphasize the bias of the sign, the way in which a sign portrays an object not neutrally, but from a distinct perspective. "Turkey and pumpkin pie signify Thanksgiving as festive. The cross and the lamb both refer to Jesus but as a martyr and as a fount of gentle love respectively" (p. 84).

Besides discussing the bias of the sign and its implications for the study of style and expressivity, Lidov develops a theory of the relationship between signifiers and signifieds (to use the better-known Saussurian terminology) which emphasizes the manner in which, in artistic practices, the form of signifiers is often explored and elaborated to the relative (or complete) exclusion of signifieds. "The elaboration of signs is fundamentally paradoxical. As signs become more elaborate, they tend to lose or loosen their hold on their objects" (p. 126). In general, Lidov suggests that as semiosis becomes increasingly elaborated, a competitive relationship emerges between structure and reference (p. 127). This viewpoint is in some senses structuralist, but this is structuralism in a dialectical relationship with pragmatics. "We can return to structuralist semiotics not as an alternative to pragmatism, but as its supplement. Sense is not the whole of meaning, but we do make sense of signs by grasping their structure" (p. 128).

In addition to retooling Peirce and offering an original analysis of the relationship between structure and reference, Lidov also makes a contribution to the study of temporality by introducing the notion of the processive sign.

In a processive sign [extended temporal engagement] is a sign factor: A processive sign is a sign in which the representamen, the object, or the interpretant is a process. A processive sign imposes on us. It commands our involvement or it captures our attention by sensory enticement and/or by 
engaging us in problems of perception, comprehension, or interpretation (p. 182).

These are the main contributions made by Lidov towards a specifically aesthetic semiotic theory. Throughout the book, other topics are also developed. Notably, Lidov describes further developments in his influential approach to the role of the body in musical semiosis. It was in this area that Lidov made his best-known contributions to musical semiotics, and while his basic position is not changed in the present work, certain important clarifications are offered.

Throughout the book, Lidov tends towards extreme economy, selecting only the most important topics and discussing them with great concision. This strategy is often successful, but sometimes it leaves gaps. For example, the specific examples and analyses offered by Lidov are always brief, developed only to the point of supporting very general theoretical claims. Granted, they are not meant to serve the same purpose as the highly nuanced analyses put forward by Monelle, but they are bound to leave specialists in any particular area feeling the need for more illustration than is given. Similarly, Lidov's treatment of certain thorny theoretical issues could be expanded considerably. To compare once again to Monelle, Lidov's treatment of textuality remains too closely attached to simpler structuralist ideas. Some of these lacunae are the result of an overall avoidance of any kind of social context or specific historical narrative, as already noted. Lidov does begin to move a little towards social theory in the last section of the book, where he considers possible consequences of his approach for pedagogical practice and the philosophical problem of free will, but this material is notable for its less theorized tone, relative to what has gone before.

At no time have musical semiotics and semiotics in general been unified fields, and these books do not change that. Both succeed in making significant contributions to the semiotic study of music, but in ways which are, at least in terms of stated ideological commitments, quite different. There are also differences in terms of specific coverage of topics, and style of presentation. However, there are important similarities beneath the divergent surfaces. Monelle rejects systematic thought, and yet clings to certain of its associated privileges and habits. Lidov by contrast argues in favour of system, and yet presents a final product which is more of a toolkit than a totalizing theory. In this respect, both Lidov and Hatten preserve the abstractive, systematizing flavour of earlier semiotics, but are more modest in terms of grand claims to completeness or universality. Lidov continues within structuralism, and Monelle explores poststructuralism, but the ambivalent nature of each enterprise causes them to converge towards a kind of pluralist, pragmatic middleground.

Monelle has in certain respects successfully integrated aspects of postmodernism, itself an ill-defined and polymorphous term. However, there are reservations which must be stated. The work is full of phrases with a Heideggerian ring, especially when Monelle speaks of theory as a means to "allow each object to disclose itself as fully as possible" (p. 231). But Monelle 
presents no extended engagement with the problematic influence of Heidegger. One result is that, throughout, the work strikes an uneasy balance between phenomenological, transcendental, and historicist perspectives; an acrobatic feat both exciting and impressive, but which may or may not form a viable method. Similarly, Monelle describes his own work as "dialogic" (p. 13), but offers no extended treatment of Bakhtin, and expressly avoids questions of the situated and politicized enunciation which a dialogic approach entails. In a similar vein, Foucault is evoked on several occasions but the essential intertwining of power and discourse is avoided. And finally, there are prominent postmodern thinkers who are not mentioned at all: especially Deleuze. It would have been interesting to see how Monelle's conception of theory would have negotiated with Deleuze and Guattari's view of philosophy as the construction of concepts and the laying out of a plane of immanence.

Lidov is more circumspect in his treatment of sources, partly because he set himself a less ambitious task. He certainly succeeds in updating the structuralist approach, and on that level has achieved what he set out to do. However, the book abandons one of the central aspects of the structuralist spirit, in that it does not link all of its components into an overarching total model. On this level, Lidov's work is also postmodern, or at least it represents a rationalism which has become humble in response to the postmodern challenge.

In summary, both of these books are important contributions to musical semiotics, and are to be recommended highly. For specialists in the field they are essential position statements, and will be influential. For those seeking an introduction to the field, they will serve as well as anything, and will do so even more effectively if read side by side, since they tend to correct each others' oversights in many instances. The ultimate questions of whether the options they suggest are truly divergent, and whether semiotics in the future will follow one path or the other, must wait for the time being.

William Echard

Rita Steblin. Die Unsinnsgesellschaft. Franz Schubert, Leopold Kupelwieser und ihr Freundeskreis. Wien: Böhlau, 1998. xiv, 490 pp. ISBN 3-205-98820-5 (hardcover).

Musicology belongs to those fields in the humanities that require a knowledge of foreign languages. Many of us opt to research the lives and works of composers who were active in non-English speaking countries, struggling more or less successfully with relevant primary sources and secondary literature. Difficulties tend to arise when scholars attempt to comprehend primary sources which date from earlier centuries. In the case of Rita Steblin's book Die Unsinnsgesellschaft. Franz Schubert, Leopold Kupelwieser und ihr Freundeskreis, readers should be comfortable with early nineteenth-century Viennese or at least have at hand a German-English dictionary published in Austria. 